\title{
PENGEMBANGAN PENDIDIKAN HUMANIS RELIGIUS DI MADRASAH
}

\author{
Hibana, Sodiq A. Kuntoro, Sutrisno \\ Universitas Cokroaminoto Yogyakarta, Universitas Negeri Yogyakarta, UIN Yogyakarta \\ hibanayusuf@gmail.com, trisno_63@yahoo.com,
}

\begin{abstract}
Abstrak
Penelitian ini bertujuan untuk: (1) mengkaji konsep pendidikan humanis religius di Madrasah, (2) mengkaji strategi pengembangan pendidikan humanis religius dalam proses belajar mengajar di kelas, (3) mengkaji konsep pengembangan sikap humanis religius siswa dalam kehidupan di madrasah, dan (4) mengkaji dan menganalisis konsep pengembangan budaya kehidupan yang humanis religius di madrasah. Metode Penelitian: kualitatif, menggunakan paradigma naturalistik fenomenologi. Penelitian dilakukan di MAN Wonokromo Bantul dan MAN Lab UIN Yogyakarta. Tahap penelitian: (1) pengumpulan data, (2) reduksi data, (3) penyajian data, (4) penarikan kesimpulan. Hasil penelitian adalah: 1) terdapat lima nilai dasar pada konsep pendidikan yang humanis dan religius; (2) pengembangan pendidikan humanis religius dalam proses belajar mengajar di kelas dilakukan dengan menyediakan sarana yang memadai, menciptakan suasana belajar yang nyaman, membangun guru yang berwibawa dan berkarakter, menyelenggarakan proses pendidikan yang konstruktif, dan membangun lingkungan belajar yang kondusif. (3) pengembangan sikap humanis religius siswa di madrasah dilakukan melalui proses belajar mengajar yang mengembangkan nilai, memberikan banyak pengalaman kepada siswa, dan menciptakan lingkungan yang kondusif. (4) pengembangan budaya humanis religius di madrasah dilakukan dengan cara pemantapan visi madrasah, membentuk tim inti, membangun kelas inti, dan menciptakan kelas imbas.
\end{abstract}

Kata Kunci : Pendidikan Humanis, Pendidikan Religius, Madrasah

\section{DEVELOPING RELIGIOUS HUMANISTIC EDUCATION IN ISLAMIC SCHOOL}

\author{
Hibana, Sodiq A. Kuntoro, Sutrisno \\ Universitas Cokroaminoto Yogyakarta, Universitas Negeri Yogyakarta, UIN Yogyakarta \\ hibanayusuf@gmail.com, trisno_63@yahoo.com,
}

\begin{abstract}
This research is aimed at: 1) Studying the concept of religious humanistic aducation in the teaching process. 2) Studying and analyzing the concept of religious humanistic attitude of the students in Islamic Schools, and 3) studying and analyzing religious humanistic cultural living development concept in islamic school.This research is qualitative research using naturalistic paradigm. This research was conducted in MAN Wonokromo Bantul and MAN Lab UIN Yogyakarta. The data source and informants in this research are Islamic school principals, class teachers, officers, students, and parents. All the informants are primary data source obtained deeply to get the data about religious humanistic education development.Data collection was conducted by using observation, deep interviews and dokumentation. This research used two analysis models. They are analysis in sharpening data validity, and analysis through data interprelation as a whole.Tthera are four interrelating steps, they are: 1) data collection, 2) data reduction, 3) data display, and 4) conclution drawing and verification. This is in line with analysis model asserted by Mc Coord \& Mc Coord.The research findings in general are: 1) there are five basic values of humanistic education and religious concept; 2) Religious humanistics education concept in teaching learning process in class is done by providing adequate facilities, conducting comfortable learning atmosphere, building strong character, conducting constructive education process, and developing conducive learning environment. 3) religious humanistic attitude development of the students in Islamic schools is conducted through teaching learning proces developing value, giving many experiences to the students and creating conducive environment. 4) developing religious humanistic cultural in Islamic Schools is done by Islamic schools by stabilizing vision, building core team, building core class, and creating feedback classroom.
\end{abstract}

Keywords: Humanistic Education, Religious Education, Islamic school. 


\section{PENDAHULUAN}

Masyarakat Indonesia menghadapi berbagai krisis yang belum dapat diatasi secara tuntas. Banyak persoalan di tengah masyarakat yang masih menjadi tantangan dan pemikiran. Salah satu yang menjadi sorotan tajam dunia pendidikan adalah krisis karakter. Hal itu ditunjukkan dengan maraknya kasuskasus pelanggaran norma, kenakalan remaja, dan kehidupan yang semakin bebas jauh dari nilai-nilai agama. Selain itu juga terjadi perubahan nilai dalam kehidupan masyarakat. Sebagian generasi muda melakukan pelanggaran nilai agama, budaya, social dan sebagainya.

Karakter tidak dapat dilepaskan dari peran pendidikan yang ada di Indonesia. Proses pendidikan telah membentuk struktur bangunan pemikiran seseorang hingga terbangun struktur kepribadian. Struktur masyarakat menentukan pola pikir dan pola perilaku dalam kehidupan sehari-hari. Dengan demikian pendidikan memiliki kontribusi yang sangat besar terhadap kualitas sumber daya manusia yang ada, karena mereka semua adalah produk dari proses pendidikan. Kualitas suatu bangsa dapat dilihat dari bagaimana kualitas pendidikannya.

Berkait dengan hal tersebut, Sodiq A.

Kuntoro memandang bahwa kehidupan saat sekarang bila dicermati secara mendalam masih banyak realita yang belum sesuai dengan idealita. Masih terjadi kesenjangan antara seharusnya dan senyatanya. Banyak proses pendidikan yang mengalami dehumanisasi, karena pengetahuan dan nilai-nilai masih diartikan sebagai obyek pemilikan (having), dimiliki dan dikuasai secara kognitif. Belum cukup menjadi pengetahuan dan nilai yang mampu membangun perubahan diri (being). Ada keterpisahan dan kesenjangan antara pengetahuan dan nilai dengan diri manusia. Karena keterpisahan itulah manusia mengalami proses dehumanisasi (Kuntoro, 2008, p.16).

Pengetahuan siswa memang tidak sepenuhnya sebatas kognitif, aspek afektif dan psikomotor juga telah tersentuh. Namun aspek kognitif masih mendominasi aktivitas pendidikan pada umumnya. Akibatnya pendidikan kurang mengarah pada pembangunan sikap mental dan pembentukan karakter. Pendidikan ke arah penyadaran dan menumbuhkan rasa tanggung jawab terasa masih kurang. Dalam proses pembelajaran, siswa masih cenderung diperlakukan sebagai obyek pasip yang sekedar menjadi penerima dari pengetahuan yang dipaksakan oleh guru.

Persoalan lain adalah pemahaman terhadap peserta didik yang mengalami degradasi. Realita menunjukkan bahwa pendidikan di Indonesia belum cukup memahami anak sebagai seorang pribadi yang memiliki kekhasan dan keunikan tersendiri. Degradasi tersebut sudah berlangsung sejak awal pemerintahan Indonesia. Pada masa reformasi saat ini ternyata belum cukup mampu untuk mengangkat pemahaman tentang hakekat peserta didik, sehingga degradasi pemahaman masih berlangsung hingga saat ini (Lie, 2006, p. 79).

Bila dicermati lebih jauh, pendidikan yang berlangsung saat ini memang masih cenderung bersifat tekstual. Pembelajaran masih terpaku pada materi yang tertulis di buku, terlepas dari konteks kehidupan yang dialami dalam praktik sehari-hari. Materi dipelajari lebih untuk orientasi ujian, baik ujian semester atau ujian akhir. Implementasi dari nilai-nilai yang terkandung dalam materi pelajaran terabaikan. Metode pengajaran kurang melayani kebutuhan siswa, namun masih menekankan pada buku teks semata. Pendidikan hanya terbatas pada ruang kelas, sehingga terasing dari kehidupan sosial. Tata tertib yang ada di kelas dan di sekolah cenderung top down, ditentukan secara sepihak tanpa melibatkan pemikiran siswa dan kurang ada proses penyadaran. Penggunaan hukuman fisik atau rasa takut kadang masih digunakan sebagai alat untuk membangun disiplin siswa. Dengan demikian dapat dikatakan bahwa kegiatan pendidikan masih mengalami dehumanisasi, karena kurang melibatkan partisipasi siswa dalam mengembangkan pengetahuan, sikap dan kepribadian siswa.

Lebih lanjut pendidikan masih berorientasi pada nilai angka, daripada pengembangan kepribadian. Siswa belajar lebih terpaku pada penguasaan materi secara kognitif dengan target lulus ujian, bukan hasil pengetahuan yang dapat membangun dan mengembangkan kualitas diri. Dengan demikian esensi nilai yang ada dalam materi menjadi lepas dari tujuan pengembangan diri. Terlebih dengan system ujian nasional yang dituntut untuk lulus 100 persen. Apalagi dengan beban kurikulum yang semakin padat, sementara 
lulus ujian Nasional menjadi fokus utama, maka yang terjadi siswa cenderung hanya menerima apa yang diinstruksikan demi sukses Unas. Belajar lebih bersifat pasif, siswa lebih menekankan pada mengingat data dan fakta semata. Guru dan siswa dikejar target materi yang ada dalam kurikulum, dengan target siswa dapat mengerjakan semua butirbutir soal, hingga akhirnya lulus ujian. Pendidikan religius menjadi alternatif solusi dari berbagai persoalan di atas.

Pendidikan religius, merupakan pendidikan yang mengajarkan nilai-nilai agama secara umum, apapun agamanya. Pendidikan religius penuh dengan muatan nilai moral. Pendidikan religius diharapkan menjadi salah satu ruh pendidikan di Indonesia. Hal tersebut sejalan dengan falsafah pendirian negara Republik Indonesia yang tertuang dalam dasar negara, yakni pancasila. Sila-sila yang terkandung dalam Pancasila merupakan cerminan dari kepribadian bangsa Indonesia.

Sila Pertama, "Ketuhanan yang Maha Esa", mencerminkan jiwa bangsa Indonesia yang religius. Jiwa religiusitas sebagai sila pertama dalam pancasila diharapkan dapat menjadi landasan bagi pelaksanaan sila-sila yang lain. Sila kedua "kemanusiaan yang adil dan beradab", mencerminkan kehidupan bangsa Indonesia yang santun, menghargai hak orang lain. Sila ini mencerminkan kehidupan yang humanis. Karena segala aspek kehidupan yang baik tidak dapat lepas dari konsep adil dan beradab. Hal tersebut juga terjadi dalam dunia pendidikan.

Pendidikan yang dikembangkan di bumi Indonesia idealnya adalah pendidikan yang menghargai kemerdekaan anak, dan di sisi lain juga menghargai nilai-nilai moral, spiritual, dan keagamaan siswa. Pendidikan semacam inilah yang sesuai dengan jiwa dan kepribadian bangsa Indonesia, yakni pendidikan yang humanis religius.

Selain mengembangkan nilai-nilai keagamaan, nilai etika dan moral, pendidikan religius juga mengembangkan nilai-nilai kemanusiaan. Karena agama apapun pasti menghargai nilai-nilai dasar kemanusiaan. Sesuatu yang ironis bila pelaksanaan pendidikan mengklaim sebagai pendidikan yang religius, namun di sisi lain merendahkan nilai-nilai kemanusiaan. Dengan demikian pendidikan yang religius semestinya juga pendidikan yang humanis, demikian juga sebaliknya. Na- mun kenyataannya pendidikan yang humanis belum tentu menyentuh nilai-nilai religius, dan pendidikan yang religius kadang juga kurang humanis.

Selain itu pendidikan yang dikembangkan semestinya pendidikan yang dapat meningkatkan harkat kemanusiaan manusia. Belajar tidak hanya menghasilkan pengetahuan, namun juga membangun nilai-nilai yang dapat menjadikan kepribadian dan karakter berkembang. Pengetahuan yang diperoleh hendaknya juga dapat diarahkan untuk perbaikan kehidupan, bukan sekedar mata pelajaran yang terasing dari kehidupan seharihari. Pengetahuan semestinya dibawa pada pengalaman hidup, karena pengetahuan memang untuk kehidupan. Materi yang dipelajari siswa semestinya erat dengan pengalamanpengalaman konkrit dalam kehidupan seharihari yang dihadapi dan perlu dipecahkan. Bukan sesuatu yang ada di awang-awang, jauh dari realita kehidupan. Dengan demikian pendidikan akan menjadikan seseorang lebih bijaksana dalam menyikapi berbagai dinamika dan problema kehidupan, karena apa yang dipelajari tidak lepas dari konteks kehidupan yang dialami.

Pendidikan adalah proses yang berkelanjutan. Dalam pendidikan ada proses belajar. Belajar pada hakekatnya adalah upaya untuk pengembangan diri dan untuk memecahkan masalah, bukan sekedar untuk penguasaan materi secara kognitif dan untuk ujian semata. Hal tersebut sesuai dengan konsep pendidikan menurut Ki Hadjar Dewantara, yakni pendidikan merupakan daya upaya untuk memajukan bertumbuhnya budi pekerti (kekuatan batin, karakter), pikiran, fisik, mental, intelektual, dan tubuh anak. Tiap-tiap bagian tidak dapat dipisahkan, agar supaya dapat memajukan kesempurnaan hidup, yakni kehidupan dan penghidupan anak yang dididik selaras dengan dunianya (Dewantara, 1977, p.14). Dengan demikian pendidikan sebaiknya lebih bersifat holistik, mencakup semua aspek kehidupan dan kepribadian manusia. Pendidikan yang holistik akan mampu menghasilkan pribadi yang lebih utuh dimana perkembangan intelektual, moral dan fisik terjadi secara integral dan harmoni.

Konsep idealita pendidikan di atas, yakni konsep pendidikan yang memberikan rasa aman, kemerdekaan, membangkitkan kerja sama, mendorong seseorang untuk aktu- 
alisasi diri, mengembangkan kreativitas dan kejujuran, dirasa masih jauh dari realita pendidikan yang berlangsung saat ini. Pendidikan yang ada sekarang masih cenderung formal tekstual, lebih pada penguasaan materi secara kognisi, kurang menyentuh aspekaspek yang lebih mendalam. Pendidikan juga belum sampai pada pembentukan nilai dan pengembangan hati nurani.

Sisi lain menurut Ki Hadjar Dewantara, pendidikan di Indonesia harus mencerminkan nilai-nilai kebangsaan. Pendidikan harus bertumpu pada penguatan nalar dalam berpikir dan bermoral. Pendidikan harus mampu membentuk karakter bangsa yang mandiri, tidak menjadi bangsa yang bergantung pada bangsa lain. Pendidikan jangan sampai lepas dari akar budaya bangsa, karena pendidikan memiliki peran penting dalam mendidik anak-anak negeri. Pendidikan menjadi penguat awal dan dasar bagi seluruh perjalanan hidup anak bangsa. Pendidikan harus mampu melepaskan jeratan hegemoni asing, jika tidak maka budaya bangsa akan tercerabut dan hilang dari anak-anak bangsa. Hal tersebut mengakibatkan hilangnya identitas bangsa sendiri (Dewantara, 1977, p.9). Nilai-nilai kebangsaan memang sangat penting untuk ditanamkan dalam pribadi anak, agar mereka tidak kehilangan jati diri bangsa seiring perkembangan jaman yang semakin terbuka. Nilai kebangsaan yang terabaikan dapat menjadikan individu menjadi warga yang asing di daerahnya sendiri.

Berkait dengan proses pembelajaran, maka Ki Hadjar Dewantara menekankan kepada guru untuk memberikan kebebasan dan kemerdekaan kepada anak. Bukan kemerdekaan yang leluasa, tetapi yang terbatas oleh tuntutan kodrat alam yang nyata dan menuju ke arah kebudayaan, yaitu keluhuran dan kehalusan hidup manusia. Agar kebudayaan dapat menyelamatkan dan membahagiakan hidup manusia maka perlu berdasar pada kebangsaan. Namun jangan sekali-kali melanggar atau bertentangan dengan dasar yang lebih luas, yaitu dasar kemanusiaan.

Pendidikan tidak dapat diterapkan dengan cara paksaan. Pendidikan adalah momong, among dan ngemong. Momong, berarti merawat dan memelihara anak, sehingga ia dapat tumbuh dan berkembang sesuai dengan jiwa dan pribadinya. Among, berarti menyambut dan menerima anak walau apapun kondisi dan kemampuan yang ada pada dirinya. Anak dipandang sebagai pribadi yang memiliki keunikan dan potensi tersendiri, yang dapat dikembangkan secara optimal. Sedangkan ngemong berarti memberikan kebebasan kepada anak untuk mengembangkan diri, dengan tetap memberikan bimbingan, arahan, tuntunan sehingga anak dapat mengaktualisasikan potensi yang dimiliki dengan tetap berada pada rel yang benar. (Dewantara, 1977, p. 13).

Pendidikan adalah mengelola dan membimbing anak. Guru boleh mencampuri kehidupan anak bila ia memang berada pada jalan yang salah. Guru harus menjaga kehidupan batin peserta didik, dan ia haruslah dijauhkan dari tiap-tiap paksaan. Namun guru tetap mengamati perkembangan anak agar ia dapat tumbuh sesuai dengan kodratnya. Hukuman dapat dilakukan untuk mencegah kesalahan berikutnya, namun harus sepadan dengan tingkat kesalahan yang dilakukan. Tujuan akhirnya adalah membangun pribadi yang merdeka dalam arti kata yang sebenarnya. Sebagaimana ungkapannya, "lahirnya tiada terperintah, batinnya bisa memerintah, maтрu berdiri sendiri karena kekuatan sendiri (Dewantara, 1977, pp. 11-14).

Kemerdekaan dan kemandirian nampaknya menjadi hal yang harus diperhatikan dan dimiliki oleh setiap individu. Pribadi yang merdeka, yang tidak dikuasai oleh orang lain atau bangsa lain, pribadi yang mampu mengatur dirinya sendiri dan mengatur bangsanya sendiri, serta mampu mandiri dengan memanfaatkan kekuatan dan potensi yang ada pada diri sendiri dan bangsanya sendiri.

Berkait dengan proses pendidikan, ada beberapa prinsip dasar pendidikan yang humanis, menurut Sodiq A. Kuntoro, antara lain: (1) prinsip pendidikan berpusat pada anak. Guru tidak bersifat otoriter, namun memperhatikan keterlibatan dan aktivitas anak. Pendidikan dilaksanakan secara kooperatif dan demokratis; (2) siswa adalah manusia aktif, bukan pasif. Anak akan belajar dengan aktif bila mamahami akan kebutuhannya, dan sesuai dengan bakat, minat dan kemampuannya; (3) peran guru sebagai pembimbing, motivator, penasehat, bukan penguasa kelas. Tugas guru membantu siswa untuk belajar, sehingga memiliki kemandirian dalam belajar, bukan menguasai siswa; (4) Sekolah adalah miniatur kehidupan dalam masyarakat. Karena itu pendidikan akan bermakna bila 
pendidikan itu bermanfaat dalam kehidupan masyarakat; (5) Aktivitas belajar lebih berfokus pada pemecahan masalah, bukan sekedar menghafal dan menguasai mata pelajaran; dan (6) iklim belajar harus demokratis dan kooperatif, karena setiap individu pasti akan hidup bersama orang lain, maka setiap orang harus mampu bekerja sama dengan orang lain (Kuntoro, 2008, pp. 6-7).

Konsep di atas sangat ideal untuk diterapkan dalam pembelajaran sehari-hari. Namun kenyataan di lapangan masih mengalami banyak kendala. sebagian guru masih memiliki pemahaman tentang pendidikan yang tradisional, sehingga pola pendidikan yang diterapkan juga cenderung tradisional, yakni lebih berpusat pada guru, bersifat monoton, guru sebagai sumber utama pembelajaran dan sebagainya. Oleh karena itu perlu upaya penyadaran lebih lanjut, khususnya kepada para guru yang memiliki peran sentral dalam proses pembelajaran. Guru yang baik akan mampu membawa siswa menjadi lebih baik lagi. Sebaliknya guru yang tidak baik bisa menghambat perkembangan siswa, bahkan dapat melakukan pembodohan terhadap siswa.

Pengembangan model pembelajaran yang humanis religius memang telah banyak dikaji. Salah satunya adalah hasil penelitian dari Jumarudin dkk. (Jumarudin, 2014, p. 128). Hasil penelitian yang dilakukan menunjukkan bahwa model pembelajaran yang efektif untuk menanamkan karakter positif adalah model pembelajaran yang humanis religius. Model pembelajaran tersebut menunjukkan keterlaksanaan yang tergolong baik, dengan kriteria yang efektif dan praktis. Peserta didik memiliki respon yang amat positif terhadap model pembelajaran yang humanis religius dalam pendidikan karakter di sekolah.

Menjadi sebuah kebutuhan yang mendesak untuk mengkaji secara mendalam tentang konsep pendidikan yang humanis religius sesuai dengan akar budaya bangsa. Selanjutnya diperlukan perumusan instrumen yang memadai untuk mengembangkan pendidikan yang humanis religius di sekolah. Karena pendidikan memang memegang peranan yang sangat besar bagi pembangunan bangsa.

Berdasarkan uraian tersebut maka permasalahan yang diteliti adalah: (1) konsep pendidikan humanis religius di madrasah, (2) pengembangan pendidikan humanis religius dalam proses belajar mengajar di kelas, (3) pengembangan sikap humanis religius siswa dalam kehidupan di madrasah, dan (4) pengembangan budaya/perilaku kehidupan yang humanis religius di madrasah.

\section{METODE PENELITIAN}

Penelitian ini merupakan model penelitian kualitatif, dengan paradigma naturalistik fenomenologi. Kesimpulan yang diperoleh dari penelitian ini bukan untuk mendapatkan generalisasi, namun dapat ditransfer pada populasi lain yang memiliki ciri-ciri yang sama, dengan diikuti upaya penyesuaian.

Karakteristik penelitian kualitatif naturalistik menggunakan konsep Egon G Guba (Guba dalam Muhadjir, 1993, p.126). Beberapa ketentuan dari penelitian naturalistik adalah: konteks natural, manusia sebagai instrumen, pemanfaatan pengetahuan yang tak terkatakan. Metode yang digunakan kualitatif, pengambilan sampel secara purposive, analisis data secara induktif, grounded theory. Desain penelitian bersifat sementara, hasil penelitian disepakati, modus laporan studi kasus. Selanjutnya penafsiran secara idiografik, aplikasi tentatif, dan ikatan konteks terfokus. Sedangkan kriteria kepercayaan adalah kredibilitas, transferabilitas, dependabilitas, dan konformabilitas.

Cara kerja yang dilakukan meliputi tiga tahap, yakni (1) tahap pra lapangan, (2) tahap di lapangan, (3) tahap analisis data. Guna memperoleh data yang terkait dengan problematika penelitian maka diperlukan teknik pengumpulan data yang sesuai. Mengingat penelitian ini bersifat kualitatif, yaitu studi yang mendeskripsikan hasil penelitian dalam bentuk naratif, bukan kuantitatif, maka ada empat teknik penelitian kualitatif yang dapat digunakan, yakni participant observation, pengamatan langsung, intensive interview, dan case studies. (Bogdan \& Taylor, 1992, p.32).

Adapun langkah-langkah yang dilakukan meliput: (1) pengamatan partisipatif, (2) pengamatan nonpartisipatif, (3) wawancara mendalam, (4) dokumentasi dan 4) triangulasi. Beberapa teknik tersebut dilakukan secara bertahap dan bergantian sesuai dengan fungsi dan kegunaannya. Dengan demikian masing-masing teknik dapat saling mengisi dan melengkapi. 
Penelitian naturalistik mengandalkan kekuatan pengamatan dan pengambilan data. Beberapa metode lain bersifat melengkapi, sekaligus untuk menguji dan menguatkan kebenaran data. Data yang telah diambil di lapangan, terutama melalui pengamatan, setelah selesai segera dicatat. Catatan dibagi menjadi dua, yakni deskriptif dan reflektif. Catatan deskriptif, lebih menyajikan rinci kejadian. Sedangkan catatan reflektif lebih mengetengahkan kerangka pikir, ide dan perhatian dari peneliti. (Muhadjir, 2011, p. 185).

Pemaknaan terhadap kasus perlu segera dilakukan melalui analisis data. Analisis data merupakan upaya mencari dan menata secara sistematis catatan hasil observasi, wawancara dan lainnya untuk meningkatkan pemahaman peneliti tentang kasus yang diteliti, dan menyajikannya sebagai sebuah temuan. Guna meningkatkan pemahaman tersebut, maka perlu dilanjutkan dengan upaya mencari makna atau 'meaning' dibalik fenomena yang ada. Menurut Strauss dan Corbin (Basrowi, 2008, p.206).

Ada tiga langkah besar dalam melakukan analisis data kualitatif, yakni: Pertama, Open coding. Peneliti berupaya menemukan selengkap dan sebanyak mungkin variasi data yang ada. Kedua, Axial coding. Hasil yang diperoleh kemudian diorganisasi kembali berdasarkan kategori-kategori untuk dikembangkan ke arah proposisi. Pada tahap ini dilakukan analisis hubungan antar kategori. Ketiga, Selective coding. Pada tahap ini peneliti menggolongkan kategori menjadi kriteria inti dan pendukung, serta mengaitkan antara kategori inti dan pendukungnya. Langkah selanjutnya adalah memberikan hubungan antar kategori dan akhirnya menghasilkan simpulan yang kemudian diangkat menjadi general design.

Penelitian ini mengambil setting tempat di MAN Wonokromo Bantul dan MAN Lab UIN Yogyakarta. Penelitian dilaksanakan pada tahun 2014 semester genap dan ganjil, yakni bulan Januari hingga Desember 2014. Efektif pengambilan data dilakukan di bulan januari-juni. Selebihnya untuk melengkapi data yang masih kurang.

Data yang telah terkumpul dianalisis dengan langkah sebagai berikut: (1) Pengumpulan data (data collection); (2) Pemberian kode data (data coding), (3) refleksi terhadap data (Reflection on data), (4) pemaparan data (data display), (5) penyaringan data (data distillation), menyimpulkan tema atau hasil ( $G e$ neralization of themes, (6) interpretasi terhadap hasil (story interpretation), (7) konstruk baru. Setelah hasil penelitian terhadap dua madrasah diperoleh hasil, maka selanjutnya dibuat konstruk baru. Konseptualisasi konstruk baru ini dirumuskan dengan mengambil nilai-nilai positif yang ada di MAN Wonokromo Bantul dan MAN Lab UIN Yogyakarta.

\section{HASIL PENELITIAN DAN PEMBAHASAN}

Hasil penelitian menunjukkan bahwa pendidikan bukanlah sesuatu yang sederhana. Banyak aspek yang turut berpengaruh terhadap keberhasilan progam pendidikan. Tidak hanya aspek yang ada di madrasah saja, melainkan juga lingkungan yang ada di sekitar madrasah. Semua keadaan, situasi, sarana, fasilitas, SDM, dan semua yang ada di madrasah turut memberikan kontribusi bagi kelancaran dan keberhasilan program pendidikan yang humanis religius. Pembahasan selanjutnya mengacu pada rumusan masalah yang telah dipaparkan.

Pertama, berkait dengan konsep pendidikan humanis religius di madrasah. Berdasarkan hasil telaah dan kajian terhadap beberapa teori yang ada, disesuaikan dengan kondisi yang ada di madrasah, maka konsep pendidikan yang humanis religius dapat diformulasikan secara umum. Konsep pendidikan yang humanis adalah konsep pendidikan yang berbasis pada lima nilai dasar, yaitu (1) nilai kebebasan, (2) nilai kreativitas, (3) nilai kerja sama, (4) nilai kejujuran, dan (5) nilai aktualisasi diri.

Kebebasan, pada dasarnya adalah perasaan aman. Bebas dari rasa takut, hingga mampu aktualisasi diri sesuai dengan potensi yang dimiliki. Kebebasan yang dimiliki seseorang tidak boleh melanggar kebebasan orang lain. Karena kebebasan yang dilakukan tidak dapat lepas dari nurma dan aturan yang berlaku.

Kreativitas, adalah kemampuan seseorang untuk melahirkan sesuatu yang baru, baik berupa ide, gagasan, karya, dan sebagainya. Siswa memiliki kemampuan untuk berkreasi, mengungkapkan ide dan gagasan dalam proses pembelajaran. Siwa terbebas 
dari tekanan dan rasa takut, sehingga lebih mudah untuk mengaktualisasikan potensi kreativitasnya.

Kerja sama. Kerja sama dibutuhkan untuk melipatgandakan kekuatan. Seseorang dituntut untuk mampu bekerja sendiri, sekaligus bekerja bersama-sama. Nilai kerja sama ada dalam konsep humanis. Siswa merasakan kebutuhan untuk menjalin kerja sama dengan siswa yang lain dalam mencapai target dan tujuan tertentu.

Kejujuran, adalah sikap apa adanya sesuai dengan realita, bukan sikap yang dibuat-buat, demi mencari nama atau pujian. Siswa memiliki dorongan dari dalam diri untuk berlaku jujur, karena menyadari bahwa setiap perbuatan pada akhirnya akan dipertanggungjawabkan, baik secara horisontal kemanusiaan maupun fertikal ketuhanan.

Aktualisasi diri, adalah kemampuan seseorang untuk mengekspresikan segenap potensi yang dimiliki. Siswa telah mampu menyingkirkan hambatan psikologis sehingga mampu mengaktualisasikan potensi yang dimiliki. Siswa akan mendapatkan kebahagiaan dan kepuasan tersendiri bila memiliki kesempatan dan kemampuan untuk aktualisasi diri.

Adapun aspek religius merupakan aspek utama madrasah. Ada lima nilai dasar dalam pendidikan religius, yakni (1) Dimensi pengetahuan (ilmu keagamaan), yakni pengetahuan yang berkait dengan ajaran pokok agama, dan berkait dengan ibadah mahdhah; (2) dimensi keimanan (aqidah), yakni keyakinan dasar yang menyangkut keimanan. (3) Dimensi praktik keagamaan (syariah), yakni berupa praktik ibadah dan pengamalan nilainilai keagamaan; (4) dimensi pengamalan keagamaan (akhlak), yakni berupa perilaku dan sikap keseharian, berkait dengan hubungan kemanusiaan secara horisontal; dan (5) dimensi penghayatan keagamaan (ma'rifah), merupakan tingkatan tertinggi, yakni kemampuan seseoran untuk menangkap nilai esensial dari ajaran agama dan amal ibadah yang dilakukan.

Pendidikan yang humanis religius adalah pendidikan yang mampu mengembangkan segenap potensi yang dimiliki individu dengan berbasis pada nilai-nilai dasar kehidupan, yakni kebebasan, kreativitas, kerja sama, kejujuran, dan aktualisasi diri, dengan mengaitkan segala aktivitas yang dilakukan secara vertikal, yakni nilai-nilai ketuhanan. Pendidikan bukanlah aktivitas yang bebas nilai, tetapi justru menjadi sarana untuk mengantarkan seseorang menjadi pribadi yang bermanfaat, dan menjadi hamba Allah yang mulia.

Kedua, Pengembangan pendidikan humanis religius dalam proses pengajaran di kelas. Guru memiliki peran yang amat sentral dalam mengembangkan suasana pembelajaran di dalam kelas. Berkait dengan kemampuan guru, berdasarkan hasil wawancara dan observasi, secara umum guru memiliki kemampun akademis yang memadai. Guru juga mampu mengelola proses belajar mengajar di dalam kelas dengan baik.

Hal penting yang masih perlu dikuatkan adalah pemahaman guru terhadap substansi mengajar. Bahwa mengajar sesungguhnya bukan hanya transfer ilmu pengetahuan. Substansi mengajar selain mengembangkan pengetahuan adalah membangun nilai, karakter, dan sikap mental positif. Mengajar juga melatih siswa untuk menyelesaikan masalah yang ada di lingkungannya sesuai dengan tahap kemampuannya. Selain itu juga mengembangkan ide-ide konstruktif, membangun inspirasi dan cita-cita yang tinggi untuk kepentingan yang lebih luas. Hal inilah yang masih belum cukup dimiliki oleh para guru.

Berdasarkan hasil telaah terhadap data observasi dan wawancara yang telah dilakukan, maka pengembangan pendidikan humanis religius dalam proses pengajaran di kelas dapat diformulasikan sebagai berikut: 1) Membangun paradigma yang tepat bagi guru terkait dengan konsep pembelajaran yang humanis religius; (2) membangun kesadaran guru terkait dengan substansi mengajar, yakni bukan hanya menyampaikan pengetahuan, tetapi juga membangun nilai dan karakter; (3) Menguatkan kepribadian dan karakter guru, sehingga semua itu akan mengimbas kepada siswa; (4) membangun hubungan komunikasi yang akrab, ramah dan interaktif, sehingga siswa lebih leluasa untuk belajar dan aktualisasi diri; (5) Menyediakan banyak aktivitas dan kegiatan, baik di dalam kelas maupun di luar kelas yang melibatkan siswa dan guru, untuk kemudia dilakukan refleksi.

Ketiga, Pengembangan sikap humanis religius siswa dalam kehidupan di madrasah. Langkah membangun suasana yang humanis 
religius diawali dari pimpinan madrasah, kemudian diikuti oleh para guru dan pegawai yang lain. Apabila hal itu telah terbangun maka bukan hal yang sulit untuk mengajak dan mengkondisikan siswa mencapai tujuan yang diharapkan.

Berkait dengan pengembangan sikap humanis religius siswa dalam kehidupan di madrasah dapat diformulasikan sebagai berikut: (1) Membangun pandangan, sikap dan perilaku kepala sekolah, pendidik, dan tenaga kependidikan untuk lebih humanis dan religius. Karena sikap dan perilaku guru akan mudah sekali mengimbas kepada siswa; (2) membangun kesadaran siswa untuk lebih bersikap positif. Karena perilaku siswa sesungguhnya wujud dari pengetahuan dan pemahaman yang dimilikinya; (3) menyelenggarakan berbagai program kegiatan secara terrencana yang mengarah pada pembentukan jiwa yang humanis religius. Semakin banyak jenis kegiatan maka semakin terbuka pelung siswa untuk mendapatkan pengalaman dan pelajaran hidup; (4) Memberikan penguatan kepada siswa yang menunjukkan prestasi, baik bersifat akademik maupun nonakademik. Hadiah dan penguatan jauh lebih efektif dibandingkan dengan sangsi dan hukuman.

Keempat, Pengembangan budaya kehidupan yang humanis religius di madrasah. Budaya yang terbangun di madrasah merupakan kekuatan tersendiri yang akan membawa siswa bergerak ke arah nilai budaya yang ada. Karena itu membangun budaya positif amatlah penting. Madrasah yang berhasil membangun budaya positif berarti memiliki modal yang amat berharga untuk mendidik dan mengarahkan siswa menjadi lebih baik.

Kehidupan di dalam madrasah adalah sebuah sistem yang melibatkan semua orang, perangkat, dan berbagai sarana prasarana yang ada di dalamnya. Berdasarkan hasil observasi dan wawancara yang telah dilakukan maka pengembangan budaya kehidupan yang humanis religius di madrasah dapat diformulasikan sebagai berikut: Petama, membangun visi lem-baga yang mengandung nilai humanis religius. Visi adalah mimpi dan cita-cita lembaga yang ingin dicapai. Oleh karena itu menguatkan visi adalah upaya awal yang harus dilakukan. Kedua, menetapkan nilai yang ingin di kembangkan di madrasah. Dengan menetapkan nilai maka semua sivitas akademika akan lebih fokus untuk membangun dan mengembangkan nilai tersebut. Misalnya nilai religiusitas, kedisiplinan, kerja keras, kejujuran, dan rasa ingin tahu. Ketiga, menciptakan suasana madrasah yang damai. Kedamaian dan kebahagiaan adalah ruhnya kehidupan. Program apapun yang diselenggarakan tentu jangan sampai merenggut kedamaian dan kebahagiaan yang semestinya dinikmati oleh siswa. Siswa akan lebih mampu mengaktualisasikan potensi yang ada bila dalam suasana yang damai tanpa tekanan, ancaman, dan suasana takut. Keempat, membangun lingkungan madrasah yang lebih kondusif. Lingkungan memberi pengaruh amat besar bagi keberlangsungan lembaga. Lingkungan yang kondusif memberikan kekuatan tersendiri bagi madrasah untuk mencapai hasil. Oleh karena itu sebagian dari tugas madrasah adalah turut membina lingkungan; Kelima, bekerja sama dan bersinergi dengan lingkungan sosial. Hal itu akan meringankan tugas madrasah dalam membimbing dan mengarahkan siswa menjadi lebih baik. Madrasah tidak boleh berkembang sendiri, terlepas dari lingkungan sosialnya.

Demikian itulah beberapa hal terkait dengan pembahasan dan pemaknaan data yang telah dideskripsikan di depan. Selanjutnya berdasarkan pengalaman dari dua madrasah yang telah diuraikan di atas maka pelajaran yang dapat diambil adalah kekuatan utama lembaga terletak pada beberapa hal, antara lain: (1) Pimpinan atau guru yang menggerakkan, merupakan kunci awal berkembangnya madrasah. Minimal ada dua orang yang mampu menjadi penggerak, maka berkembanglah lembaga tersebut. (2) Kultur madrasah adalah kekuatan lembaga. Madrasah yang memiliki kultur positif dan kondusif menjadi mesin penggerak bagi kemajuan siswa. Karena setiap siswa yang berada di dalamnya akan terbawa arus untuk mengikuti kultur yang ada tanpa disadarinya. (3) Aktivitas kegiatan yang beragam memberikan pengayaan nilai bagi siswa. Belajar bukan hanya di kelas, namun seluruh aktivitas yang direncanakan dapat menjadi sumber belajar bagi siswa. (4) Lingkungan yang kondusif, memberi kontribusi yang besar bagi pengembangan siswa. Madrasah akan sangat terbantu oleh lingkungan masyarakat yang aktif. Maka menjadi bagian dari program madrasah untuk membangun lingkungan yang menggerakkan. 


\section{Konstruk Baru}

Berdasarkan keunikan dan keunggulan masing-masing madrasah yang telah diuraikan di atas maka selanjutnya dapat dirumuskan sebuah konstruk baru. Konstruk baru ini diperlukan untuk membangun madrasah yang bernilai humanis religius. Madrasah yang humanis religius adalah madrasah yang mampu mengembangkan nilai-nilai humanisme dalam budaya kehidupan sehari-hari dengan berlandaskan pada nilai-nilai religiusitas.

Penyusunan konstruk baru ini tidak lepas dari kondisi yang ada di MAN Wonokromo Bantul dan MAN Lab UIN Yogyakarta. Keunikan dan keunggulan yang ada di masing-masing madrasah tersebut kemudian diambil substansinya. Selanjutnya dirumuskan konstruk baru, berupa konseptualisasi pengembangan pendidikan yang humanis religius. Pola kerja yang dilakukan dapat digambarkan sebagai berikut.

Madrasah yang humanis religius adalah madrasah yang mengembangkan nilainilai dasar yang terkandung dalam konsep humanis dan religius. Nilai-nilai dasar tersebut diterapkan dalam kehidupan di madrasah secara bertahap sesuai dengan kemampuan yang dimiliki. Banyak aspek yang berpengaruh terhadap perwujudan lembaga yang humanis religius. Semakin kuat aspek yang memberikan dukungan maka semakin tinggi nilai dan kualitas lembaga dari sisi humanis religius.

Upaya membangun nilai humanis religius di madrasah ditentukan oleh banyak pihak, antara lain (1) kepala sekolah yang mampu menjadi motivator. (2) guru sebagai penggerak. Minimal ada dua guru yang mampu menjadi penggerak, maka telah mampu mewarnai madrasah. (3) program kegiatan yang beragam. Setiap kegiatan dapat memberikan pengalaman dan nilai bagi siswa. (4) Sarana belajar yang layak dan memadai. (5) Kultur/budaya madrasah yang kondusif. Kultur yang baik merupakan kekuatan yang amat besar untuk menggerakkan siswa. (6) lingkungan sosial masyarakat yang mendukung. (7). orang tua siswa yang mendukung keberhasilan anak-anaknya.

Berkait dengan hal tersebut maka ada beberapa langkah yang perlu dilakukan, berupa konseptualisasi tentang strategi untuk membangun lembaga yang humanis religius. Beberapa hal yang perlu diperhatikan antara lain sebagai berikut:

Pertama adalah Pemantapan visi madrasah. Visi merupakan tujuan tertinggi yang ingin dicapai oleh suatu lembaga. Visi yang mantap akan menjadi landasan dalam merencanakan dan melaksanakan program. Visi madrasah menjadi ruhnya lembaga dan merupakan mimpi dan cita-cita yang akan dicapai. Melalui visi yang jelas, maka kepala sekolah, guru, karyawan dan seluruh sivitas akademika akan memiliki kesamaan cita-cita dan langkan untuk bisa mencapainya.

Kedua, adalah Membentuk Tim Inti. Tim inti ini merupakan tim kecil yang dipilih dari beberapa guru. Mereka sebagai tim utama dan kekuatan inti yang berfungsi sebagai penggerak, motivator dan inspirator bagi guru dan siswa yang ada. Tim ini juga memerankan diri sebagan 'think tank', memikirkan ide-ide konstruktif bagi pengembangan lembaga. Tim ini bisa dikatakan sebagai tim penjamin mutu yang mampu bekerja lintas sektoral, langsung berada di bawah kepala madrasah.

Ketiga, Membangun kelas inti. Kelas inti adalah kelas yang dipilih untuk menjadi 'pilot project' dalam membangun dan mengembangkan lembaga. Kelas inti dikelola dan diolah sedemikian rupa, sehingga menjadi kelas yang berprestasi, tidak hanya prestasi akademik, namun juga prestasi nonakademik. Melalui kelas inti inilah visi madrasah diwujudkan. Cermin madrasah ada di kelas ini. Kelas yang telah dibangun sedemikian rupa ini akan memotivasi dan menginspirasi kelaskelas lain untuk melakukan hal yang sama.

Keempat, menciptakan kelas imbas. Kelas imbas adalah semua kelas selain kelas inti yang disiapkan untuk melakukan identifikasi terhadap nilai-nilai yang ada di kelas inti. Nilai-nilai yang ada di kelas inti menjadi cermin dan rujukan bagi kelas-kelas lain untuk mengembangkannya. Ibarat meciptakan sebuah bangunan, maka pola bangunan ada dan tercermin di kelas inti.

Berdasarkan skema di atas dapat dipahami bahwa langkah untuk membangun lembaga yang humanis religius diawali dari pemantapan visi lembaga. Karena visi inilah yang akan menuntun arah gerak dan program lembaga. Selanjutnya dibentuk tim inti yang terdiri dari beberapa guru pilihan yang mampu menggerakkan orang lain. Program madrasah 
dilakukan dengan berbasis kelas dan lingkungan. Untuk itu dipilih kelas khusus sebagai kelas inti yang dikelola sedemikian rupa sehingga mampu mencerminkan visi misi madrasah. Kelas inilah yang menjadi 'master' bagi kelas-kelas lain. Selanjutnya kelas lain berfungsi sebagai kelas imbas. Kelas imbas melakukan identifikasi, mengikuti dan meniru karakter kelas yang sudah jadi. Maka melalui gerakan yang mengembang akan dihasilkan profil lembaga yang humanis religius sebagaimana di harapkan.

Lingkungan dan kultur madrasah memberikan pengaruh yang amat besar. Karena itu perlu strategi khusus untuk membangun kultur madrasah. Kepala madrasah sebagai top leader memegang peran besar dalam upaya tersebut. Sedangkan guru menjadi ujung tombak yang akan berhadapan langsung dengan siswa setiap hari.

Guna mencapai visi lembaga, yakni pengembangan pendidikan yang humanis religius maka dapat dicapai dengan menerapkan teori Circle, yakni dengan menciptakan wilayah inti yang kemudian diikuti oleh wilayah yang lebih jauh. Wilayah inti dipilih dari satu kelas yang disiapkan dan dikelola sedemikian rupa. Dari wilayah inti inilah kemudian berkembang keluar menuju wilayah yang lebih luas, yakni kelas kelas lain sebagai kelas imbas. Akhirnya dapat terbentuk lingkungan sekolah yang kondusif, dan pada saatnya dapat tercapai visi madrasah yang dicita-citakan.

\section{SIMPULAN DAN SARAN}

Berbagai pemikiran berkait dengan pendidikan humanis religius telah dipaparkan di depan. Selain itu juga realita yang ada di lapangan, telah digambarkan secara ditail. Berdasarkan hasil penelitian dan pembahasan yang telah diuraikan di atas maka dapat diambil beberapa kesimpulan.

Pertama, konsep pendidikan yang humanis religius adalah konsep pendidikan yang berbasis pada nilai-nilai dasar yang terkandung dalam humanisme dan religiusitas. Lima nilai dasar itu adalah kebebasan, kreativitas, kerja sama, kejujuran, dan aktualisasi diri. Sedangkan nilai religiusitas meliputi pengetahuan (ilmu keagamaan), keimanan (aqidah), praktik keagamaan (syariah), pengamalan keagamaan (akhlak), dan penghayatan keagamaan (ma'rifah).
Dengan demikian pendidikan yang humanis religius adalah pendidikan yang berupaya mengembangkan segenap potensi yang dimiliki individu dengan berbasis pada nilainilai dasar kehidupan, yakni nilai kebebasan yang bertanggung jawab dengan mengaitkan segala aktivitas yang dilakukan secara vertikal berupa nilai-nilai ketuhanan. Pendidikan bukanlah aktivitas yang bebas nilai, tetapi justru menjadi sarana untuk mengantarkan seseorang menjadi pribadi yang bermanfaat bagi sesama, dan menjadi hamba Allah yang mulia.

Kedua, Pengembangan pendidikan humanis religius dalam proses belajar mengajar di kelas, dapat dilakukan dengan berbagai cara. Beberapa strategi yang perlu dilakukan antara lain: (1) menyediakan sarana prasarana yang memadai; (2) menciptakan suasana belajar yang nyaman. Anak akan belajar dengan baik bila ia merasa nyaman, terbebas dari tekanan, rasa cemas dan takut; (3) membangun guru yang berwibawa dan berkarakter. Guru merupakan ujung tombak dari proses pembelajaran; (4) menyelenggarakan proses belajar mengajar yang konstruktif. Alam berfikir siswa dibangun agar apat bertumbuh dan berkembang lebih jauh lagi. Guru tidak hanya memotivasi, tapi juga menginspirasi siswa untuk terus mengembangkan diri; (5) membangun lingkungan belajar yang kondusif. Lingkungan belajar memberikan energi yang amat besar bagi siswa untuk melakukan segala sesuatu sesuai dengan nilai yang berkembang di lingkungan.

Ketiga, berkait dengan pengembangan sikap humanis religius siswa dalam kehidupan di madrasah. Upaya yang dapat dilakukan antara lain: (1) melalui proses belajar mengajar yang mengembangkan nilai; (2) menghidupkan nilai, dilakukan dengan cara memberikan banyak pengalaman kepada siswa melalui berbagai aktivitas dan kegiatan. Kemudian diikuti dengan refleksi kegiatan. 3) Menciptakan lingkungan yang kondusif bagi pengembangan pribadi siswa.

Keempat, berkait dengan upaya pengembangan budaya kehidupan yang humanis religius di madrasah. Ada beberapa langkah yang perlu dilakukan untuk membangun lembaga yang humanis religius, antara lain: (1) Pemantapan visi madrasah. Visi merupakan tujuan tertinggi yang ingin dicapai oleh suatu lembaga. Visi yang mantap akan menjadi landasan dalam merencanakan dan melaksanakan 
program; (2) membentuk Tim Inti. Tim inti terdiri dari beberapa guru pilihan, berfungsi sebagai penggerak, motivator dan inspirator bagi guru dan siswa yang ada. Minimal ada dua guru dalam tim yang memiliki motivasi tinggi dan mampu sebagai penggerak, maka cukuplah; (3) membangun kelas inti. Kelas inti adalah kelas yang dibangun untuk menjadi cermin bagi madrasah dalam pencapaian visi. Kelas ini dipilih untuk menjadi 'pilot project' dalam membangun dan mengembangkan lembaga; (4) menciptakan kelas imbas. Kelas imbas adalah kelas yang mengidentifikasi dan meniru nilai-nilai yang ada di kelas inti. Kelas inti disiapkan untuk dapat mengimbaskan nilai-nilai keunggulan yang telah dicapainya terhadap kelas-kelas lain. Nilai yang ada di kelas inti menjadi cermin dan rujukan bagi kelas-kelas lain atau kelas imbas untuk meniru, mengidentifikasi, dan mengembangkannya.

Dengan demikian beberapa poin yang dihasilkan melalui penelitian ini adalah berupa konseptualisasi tentang pengembangan madrasah yang humanis religius, yakni, pertama, Konseptualisasi gambaran madrasah yang humanis religius, yakni madrasah yang mengembangkan nilai-nilai dasar humanis (kebebasan, kreativitas, kerjasama, kejujuran, aktualisasi diri) dengan tetap berada dalam kerangka religius. Bukan humanisme yang sekuler, melainkan humanisme yang sesuai dengan nilai-nilai religius (ilmu, aqidah, ibadah, akhlak, ma'rifah)

Kedua, Faktor penentu madrasah yang humanis religius, antara lain kepala sekolah sebagai motivator, guru sebagai penggerak, program kegiatan yang beragam, sarana belajar yang memadai, kultur budaya madrasah yang kondusif, lingkungan sosial yang mendukung, dan orang tua yang responsif.

Ketiga, Langkah mengembangkan lembaga yang humanis religius, antara lain pemantapan visi madrasah, pembentukan tim inti, membangun kelas inti, menjadikan kelas imbas, hingga akhirnya terbangun lembaga yang humanis religius.

\section{Saran}

Saran dan masukan yang dapat diberikan untuk madrasa antara lain: 1) Peran kepala sekolah perlu lebih ditingkatkan untuk mengawal program lembaga. Karena kepala sekolah memiliki kekuatan dan otoritas yang besar dalam menggerakkan lembaga. Kepala sekolah memegang kunci keberhasilan lembaga. (2) Guru yang ada perlu terus dikembangkan agar para guru dalam mengajar tidak hanya berorientasi pada materi, namun lebih jauh pada pengembangan nilai dan pribadi siswa. Diskusi antar guru perlu terus dihidupkan. Melalui forum itulah hal-hal yang positif bisa dikuatkan, dan yang kurang dapat disempurnakan. (3) Lingkungan yang positif, yakni kehidupan yang religius terus dijaga dan dikembangakan agar lebih kuat dalam menggerakkan siswa. Kerja sama dan sinergi dengan lingkungan perlu lebih ditingkatkan. (4) Aspek humanis, seperti kebersihan, ketertiban perlu mendapatkan penanganan lebih agar kondisi ideal dapat lebih mudah untuk dicapai.

Selanjutnya saran untuk pemangku kepentingan, dalam hal ini adalah Kementerian Pendidikan, Kementerian Agama, dan pihak lain yang bertanggung jawab terhadap pendidikan. Guna mencapai hasil pendidikan yang lebih optimal maka perlu memberikan perhatian yang lebih serius untuk meningkatkan kualitas guru. Mengingat hasil penelitian yang menunjukkan bahwa peran guru amat besar dalam pengembangan diri dan pribadi siswa. Kualitas pendidikan ditentukan oleh kualitas guru, kualitas siswa, dan dukungan terhadap pembentukan lingkungan yang positif.

\section{DAFTAR PUSTAKA}

Bogdan \& Taylor (1982). Qualitative research for education, Boston: London.

Dewantara, K.H. (1977). Bagian pertama: Pendidikan. Yogyakarta: Majelis Luhur Persatuan Taman Siswa.

Dewey, J. (1963). Experience and education. New York: Collier Books, a Division Of Macmillan Publishing Co., Inc.

Driyarkara, N. (1980). Hominisasi dan humanisasi, telaah filsafat pendidikan. Yogyakarta: Universitas Sanata Darma.

Freire, Paulo. (2004). The politic of education: culture, power, and liberation, (Politik Pendidikan: kebudayaan, kekuasaan, dan pembebasan). Terje- 
mah: Agung Prihantoro, dkk. Yogyakarta: Pustaka Pelajar.

Hanafi, H. et al. (2007). Islam dan humanisme, aktualisasi humanisme Islam di tengah krisis humanisme universal. Yogyakarta: Pustaka Pelajar.

Jumarudin, J., Gafur, A., \& Suardiman, S. (2014). Pengembangan model pembelajaran humanis religius dalam pendidikan karakter di sekolah dasar. Journal Pembangunan Pendidikan Fondasi Dan Aplikasi.

Lickona, T. (Ed.982) . Moral development and behavior. theory, research, and social issues. New York: Holt, Rinehart and Winston.

Kuntoro, S.A. (2008). Sketsa pendidikan humanis religious. Makalah disajikan dalam diskusi dosen di fakultas ilmu pendidikan (FIP) Universitas Negeri Yogyakarta.

Muhadjir, N. (2011). Metodologi penelitian (Ed. VI). Yogyakarta: Rake Sarasin.

Sastrapratedja. (2001). Pendidikan sebagai humanisasi. Yogyakarta: Penerbi Univeritas Sanata Dharma.

Suseno, F.M. (2007). Humanisme religius vs humanisme sekuler. Makalah yang terkodifikasi dalam buku: Islam dan humanisme. Semarang: IAIN Walisanga dan Pustaka Pelajar.

Yunus, M. (2008). Sejarah pendidikan Islam di Indonesia. Jakarta: Bulan Bintang

Zuchdi, D. (2011). Pendidikan karakter, dalam perspektif teori dan praktik. Yogyakarta: UNY Press. 